\title{
EXTRACTION AND CHARACTERIZATION OF COFFEE SILVERSKIN OIL WITH POTENTIAL APPLICATION FOR ENZYMATIC SYNTHESIS OF FATTY ACIDS
}

\author{
Danyelle Andrade Mota ${ }^{a, b}$, Anna Paula Rodrigues e Silva ${ }^{a, b}$, \\ Jefferson Cleriston Barros dos Santos ${ }^{a, b}$, Milson dos Santos Barbosa ${ }^{a, b}$, Álvaro \\ Silva Lima ${ }^{a, b}$, Laiza Canielas Krause ${ }^{a, b}$, Cleide Mara Faria Soares ${ }^{a, b}$ \\ a Tiradentes University (UNIT), Av. Murilo Dantas 300, Aracaju 49032-490, Brazil; \\ ${ }^{b}$ Institute of Technology and Research (ITP), Av. Murilo Dantas 300, Aracaju 49032- \\ 490, Brazil;
}

\begin{abstract}
In this study, the coffee silverskin (CS) crude oil extraction process was investigated for further characterization of physicochemical properties and enzymatic hydrolysis for fatty acids production. The soxhlet and ultrasonic extractions showed CS oil yield similar to $3.8 \%$ and $3.1 \%$ respectively. CS oil extracted by soxhlet presented favorable physicochemical properties with the quality and was used as the feedstock for fatty acids production by enzymatic hydrolysis. The porcine pancreatic lipase immobilized on silica showed hydrolytic activity of $443 \mathrm{U} \cdot \mathrm{g}^{-1} \pm 13.4$. Therefore, was verified the potential of application in biotransformation reactions of oils with immobilized biocatalyst with fatty acids production and valorization of coffee industry waste.
\end{abstract}

Keywords: Coffee silverskin; Crude oil; Enzymatic hydrolysis; Fatty acids.

\section{EXTRAÇÃO E CARACTERIZAÇÃO ÓLEO DO SILVERSKIN DO CAFÉ COM POTENCIAL APLICAÇÃO PARA SÍNTESE ENZIMÁTICA DE ÁCIDOS GRAXOS}

Resumo: Neste estudo, o processo de extração do óleo bruto do silverskin do café (SC) foi investigado para posterior caracterização das propriedades físico-químicas e hidrólise enzimática para produção de ácidos graxos. As extrações por soxhlet e ultrassônica mostraram rendimentos de óleo SC semelhantes de 3,8\% e 3,1\%, respectivamente. O óleo SC extraído por soxhlet apresentou propriedades físicoquímicas favoráveis à qualidade e foi utilizado como matéria-prima para produção de ácidos graxos por hidrólise enzimática. A lipase pancreática suína imobilizada em sílica apresentou atividade hidrolítica de $443 \mathrm{U} \cdot \mathrm{g}^{-1} \pm 13.4$. Portanto, foi verificado o potencial de aplicação em reações de biotransformação de óleos com biocatalisador 
imobilizado com produção de ácidos graxos e valorização de resíduos da indústria cafeeira.

Palavras-chave: Silverskin do café; Óleo bruto; Hidrólise enzimática; Ácidos graxos. 


\section{INTRODUCTION}

Coffee is one of the most consumed beverages in the world with global consumption of 161 million of $60 \mathrm{~kg}$ coffee bags per year and consequently, coffee byproducts such as coffee silverskin (CS) are produced [1,2]. The CS is the thin tegument that covers the two coffee seeds and it is the only by-product generated during green bean roasting. Some studies on the utilization of coffee waste have advanced worldwide [3-5], but there is still a promising approach yet to be explored that aims at the utilization of residual CS oil. Therefore, isolation and valorization of compounds from the coffee industrial waste could be a possibility to avoid their loss. The objective of this study was the valorization of coffee silverskin wastes. CS crude oils extraction process was investigated and performed the characterization of physicochemical properties for further enzymatic hydrolysis for fatty acids production.

\section{METHODOLOGY}

\subsection{Materials}

Coffee silverskin samples were supplied by industry, located in the city of Itabaiana-Se (Brazil). Hexane for oil extraction was obtained from Synth (Brazil). porcine pancreatic lipase (PPL) and the silane precursor tetraethoxysilane (TEOS) were purchased from Sigma Chemical Co. (St. Louis, MO, USA). Other chemicals were of analytical grade.

\subsection{Oil Extraction}

The moisture removal of CS samples for subsequent oil extraction was accomplished through drying at approximately $105 \pm 2{ }^{\circ} \mathrm{C}$ for $24 \mathrm{~h}$ before lipid extraction.

Soxhlet Extraction (SE). For oil extraction from was used $20 \mathrm{~g}$ of CS with 150 $\mathrm{mL}$ hexane were refluxed by $8 \mathrm{~h}$ using Soxhlet apparatus. Following an extraction, lipids remain dissolved in the solvent solution and rotary evaporation was used to rapidly remove the excess solvent by applying heat to a rotating round-bottomed flask at reduced pressure.

Ultrasonic Extraction (UE). The ultrasonic extraction study was performed with $20 \mathrm{~g}$ silverskin sample for 30 minutes, (3 times in sequential) with $50 \mathrm{~mL}$ of hexane. The ultrasound equipment used was Ultronique (model USC-2800), frequency $25 \mathrm{kHz}$ and power US: $220 \mathrm{~W}$. After each extraction of $50 \mathrm{~mL}$ of solvent, the solid fraction was separated by filtration. After the extractions were mixed, the separation of the oil and solvent was by rotevaporation.

Any remaining traces of solvent were removed by nitrogen-assisted evaporation. All extraction methodologies were performed in triplicate and the yield (Equation 1) was calculated for later characterization of physicochemical properties:

$$
\% \text { oil recovered }=\frac{W 2-W 1}{W 3} \times 100
$$

where $W 1$ is the weight of the empty glass vial, $W 2$ is the weight of the vial plus the extracted oil and $W 3$ is the weight of the dry CS. 


\subsection{Physicochemical properties}

The quality of the oil was monitored through the physicochemical properties: acid value, free fatty acid content, iodine value, saponification value, peroxide value, density, kinematic viscosity and refractive index, were determined according to standard analytical methods recommended by Official Methods of Analysis [6].

UV specific absorbances ( $\mathrm{K}_{232}$ and $\mathrm{K}_{270}$ ) assays were carried out following the analytical methods described by the Commission Regulation of the European Union for olive and olive pomace oils (EEC) No 2568/91 [7].

The functional groups of oil were analyzed by Attenuated total reflection Fourier transform-infrared (ATR-FTIR) spectroscopy (AGILENT CARY 630 FTIR, Agilent Technologies, USA), with a scan range from of $500 \mathrm{~cm}^{-1}$ to $4000 \mathrm{~cm}^{-1}$.

\subsection{Fatty acid production by enzymatic hydrolysis of coffee silverskin oil}

The methodology previously established by Carvalho et al. [8] was used for silica synthesis. The Porcine pancreatic lipase (PPL) was immobilized by physical adsorption (PA) on silica was performed as described by Soares et al.[9]. The enzymatic hydrolytic activities of free and immobilized lipases were measured by the titration of the fatty acid which comes from the hydrolysis of residual oil the of CS according to Soares et al. [9] with modifications, the addition of Triton X-100 (18\%) on the substrate. Analyses of hydrolytic activities performed on free and immobilized lipase were used to determine Hydrolytic Activities $\left(U . g^{-1}\right)$ according to Equation 2:

$$
\text { Hydrolytic Activities }\left(\mathrm{U} . \mathrm{g}^{-1}\right)=\frac{\left(V_{A}-V_{B}\right) \times N \times 10^{3}}{t \times m}
$$

where $V_{A}$ corresponds to the is the volume of $\mathrm{KOH}$ spent in the titration of the sample $(\mathrm{mL}), V_{B}$ is the volume of the $\mathrm{KOH}$ spent in the titration of the blank $(\mathrm{mL}), N$ is the normality of the $\mathrm{KOH}$ solution, $t$ is the reaction time in minutes and $m$ is the mass of free or immobilized enzyme (g).

\section{RESULTS AND DISCUSSION}

\subsection{Oil Extraction}

In Table 1, the results extractions yield of CS oil in different methods (SE and UE) are is described. The soxhlet extraction using hexane presented $3.8 \%$ of extracted lipids, while ultrasonic extraction $3.1 \%$, no significant differences $(p \geq 0.05)$. The yield lipid of the silverskin analyzed in this study was complete in accordance with the values with the literature, with values between $2.4-3.4 \%[10,11]$. The variation found in CS lipid content can in part be attributed to factors such as the different blends of coffee varieties, the origin of the coffee beans and the processing. However, the oil extracted by soxhlet was shown to have a physical aspect (viscosity, coloring) more suitable for future applications. On the other hand, the oil obtained from ultrasound-assisted extraction was affected due to shear forces generated by the ultrasound cavitations, cell wall ruptures occurred, increasing the contact area between the solvent and the materials, intensifying the general oil extraction process and other compounds[12]. Considering the yields and quality of the extracted oil, the soxhlet extraction was 
selected as the most promising for the characterization of physicochemical properties and hydrolysis of the crude oil.

Figure 1. Extraction yield from coffee silverskin oil by soxhlet extraction and ultrasonic extraction.

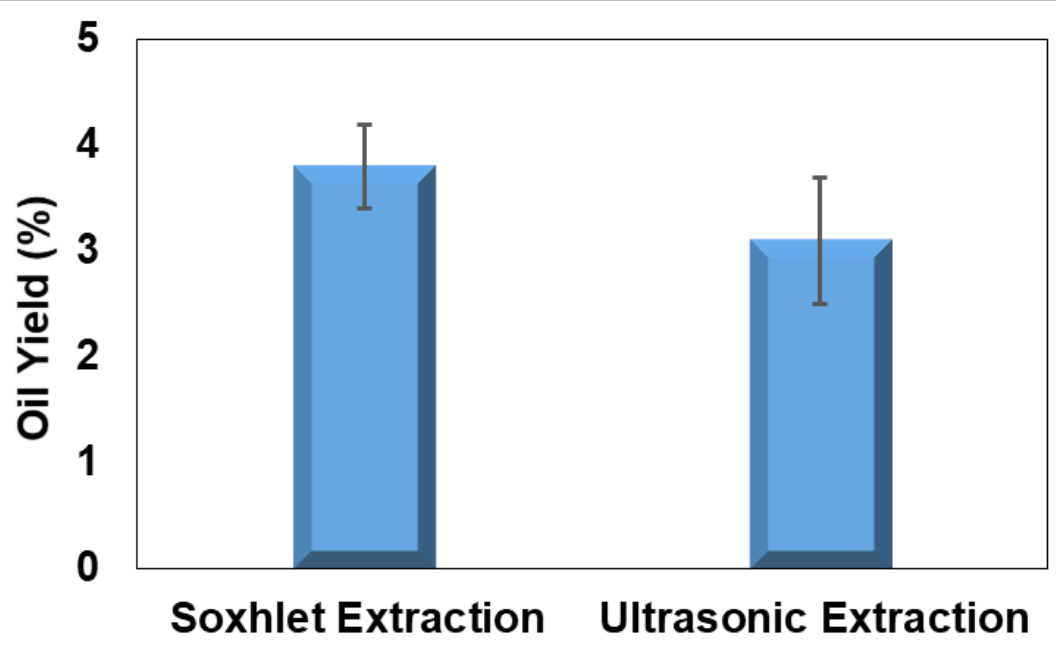

\subsection{Physicochemical properties}

The physicochemical properties related to the quality of the crude CS oil are presented in Table 1. However, in the literature, there is the characterization of the physicochemical properties of oil from other residues from coffee processing, as the spent coffee grounds (SCG) (Table 1).

The acid value of CS oil was $13.5 \mathrm{mg} \mathrm{KoH}_{\mathrm{H}} / \mathrm{g}$, an important quality parameter related to the extent of oil degradation by hydrolysis, releasing free fatty acids [13]. The iodine index was responsible for expressing the degree of oil unsaturation by breaking the double bonds and then the iodine is inserted. and is directly related to its oxidative stability [14]. The analyzed saponification index was $158.3 \mathrm{mg} \mathrm{koн}_{\mathrm{H}} / \mathrm{g}$, just below the expected range for vegetable oil (180 and $200 \mathrm{mg}_{\mathrm{koH}} / \mathrm{g}$ ). The relatively low levels of saponified matter mean that the oil remains viscous and does not freeze easily, making it suitable for applications in oil transformation [13]. The peroxide value was 5.9 $\mathrm{meqO}_{2} / \mathrm{kg}$, which indicates high resistance to oxidation of CS oil, can be store for longer [14]. Density at $40{ }^{\circ} \mathrm{C}$ amounted to $0.90 \mathrm{~g} / \mathrm{cm}^{3}$ and kinematic viscosity at $40{ }^{\circ} \mathrm{C}$ was 73.5. The refraction index at $40{ }^{\circ} \mathrm{C}$ was 1.46 , where a larger hydrocarbon chain will deflect a greater amount of light, resulting in greater refraction.

The content of water in oil was $0.6 \%$. Determination of oil moisture is important, as water favors the growth of microorganisms and product degradation. The low values of $\mathrm{K}_{232}$ and $\mathrm{K}_{270}$ in both crude CS oil indicate a low extent of oxidation. For crude oils, $\mathrm{K}_{232}$ is related to the first stage of oxidation with the presence of conjugated hydroperoxides, while $\mathrm{K}_{270}$ is related to the presence of secondary oxidation products, as aldehydes, ketones and short-chain fatty acids [15]. 
Table 1. Physicochemical properties of oil extracted from coffee silverskin.

\begin{tabular}{|c|c|c|c|}
\hline Properties & $\begin{array}{l}\text { Determined } \\
\text { values }\end{array}$ & $\begin{array}{l}\text { Haile et al. [14] } \\
\text { SCG }\end{array}$ & $\begin{array}{c}\text { Al-Hamamre et al. } \\
\text { [13] SCG }\end{array}$ \\
\hline Acid value $\left(\mathrm{mg}_{\text {кон }} / \mathrm{g}\right)$ & $13.5 \pm 0.2$ & 9.8 & 7.3 \\
\hline Free fatty acid $\left(\mathrm{mg}_{\mathrm{кон}} / \mathrm{g}\right)$ & $6.7 \pm 0.2$ & 4.9 & 3.6 \\
\hline lodine value $\left(\mathrm{gl}_{2} / 100 \mathrm{~g}\right)$ & $74.6 \pm 2.8$ & 79 & ND \\
\hline $\begin{array}{l}\text { Saponification value } \\
(\mathrm{mg} \text { кон } / \mathrm{g})\end{array}$ & $158.3 \pm 17$ & 167.3 & 173.9 \\
\hline $\begin{array}{l}\text { Peroxide value } \\
\left(\mathrm{meqO}_{2} / \mathrm{kg}\right)\end{array}$ & $5.9 \pm 0.3$ & ND & ND \\
\hline Density at $40{ }^{\circ} \mathrm{C}\left(\mathrm{g} / \mathrm{cm}^{3}\right)$ & 0.90 & 0.92 & 0.92 \\
\hline $\begin{array}{l}\text { Kinematic viscosity at } \\
40^{\circ} \mathrm{C}\left(\mathrm{mm}^{2} / \mathrm{s}\right)\end{array}$ & 73.5 & 42.6 & 55.5 \\
\hline Refractive index & $1.46 \pm 0.003$ & ND & ND \\
\hline Water content & $0.6 \pm 0.3$ & 0.03 & ND \\
\hline$K_{232}$ & $0.26 \pm 0.004$ & ND & ND \\
\hline$K_{270}$ & $0.33 \pm 0.003$ & ND & ND \\
\hline
\end{tabular}

Values are mean \pm SD of triplicate determinations

ND $=$ not determined

Figure 2 shows the FTIR spectrum used to analyze the main functional groups present in the silverskin oil. The absence of a peak after $3000 \mathrm{~cm}^{-1}$ indicates very low concentrations of impurities contained in hydroxyl groups $(\mathrm{OH})$, such as free glycerol and water, which corroborates the moisture data $(0.6 \%)$ obtained in this study. The two intense bands at $2852 \mathrm{~cm}^{-1}$ and $2924 \mathrm{~cm}^{-1}$ were due to $\mathrm{CH}_{2}$ asymmetric and symmetric stretching vibrations, attributed to the fatty acids present in the oil. Peaks between 722 $\mathrm{cm}^{-1}$ and $1466 \mathrm{~cm}^{-1}$ are associated with various $\mathrm{CH}$ groups. There was bending of cis $\mathrm{C}=\mathrm{C}$ observed at peak $722 \mathrm{~cm}^{-1}$, the vibration of $-\mathrm{C}-\mathrm{O}$ ester groups which corresponded to the large area at peak $1158 \mathrm{~cm}^{-1}$ and $\mathrm{C}=\mathrm{O}$ stretching related to peak $1720 \mathrm{~cm}^{-1}$ [16]. 
Figure 2. FTIR of extracted silverskin oil.

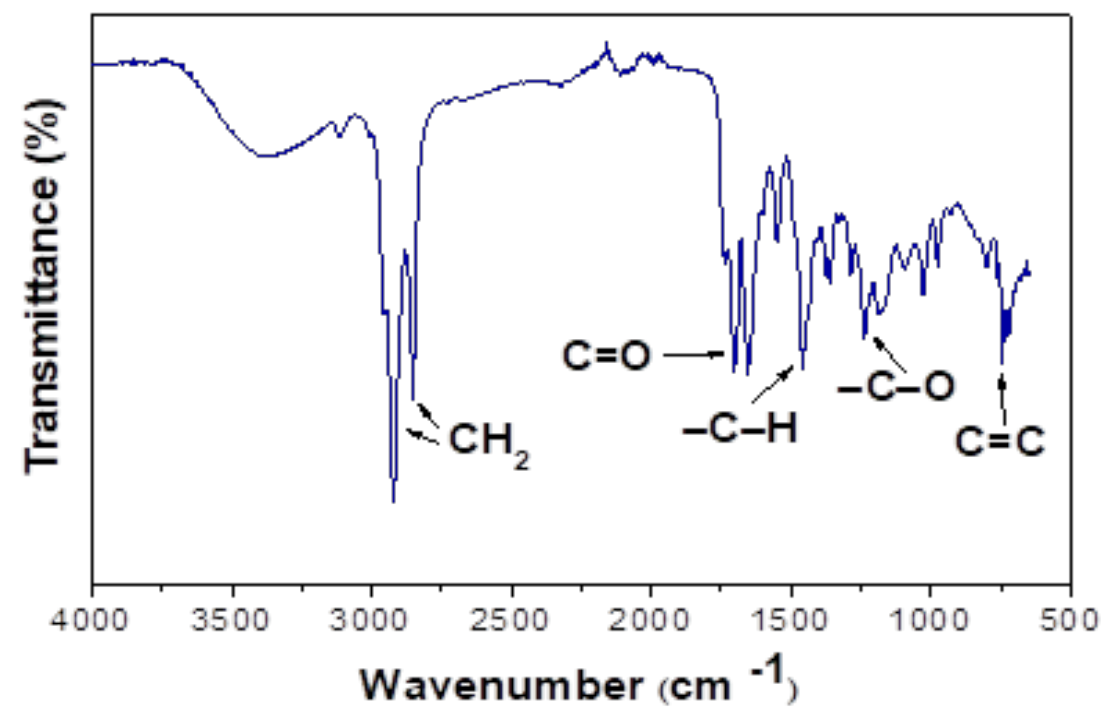

\subsection{Fatty acid production by enzymatic hydrolysis of coffee silverskin oil}

PPL immobilized on silica showed hydrolytic activity of $443 \mathrm{U} . \mathrm{g}^{-1} \pm 13.4$ during the production of fatty acids. The essential requirement to produce fatty acids by enzymatic hydrolysis is biocatalyst hydrolytic activity. The PPL is $s n-1,3$ regiospecific lipases and catalyzes the hydrolysis reaction, preferentially release fatty acids from positions 1 and 3 of triacylglycerides to give free fatty acid and di- and or monoglycerides $[17,18]$. Therefore, the application of this biocatalyst for fatty acid production is promising.

\section{CONCLUSION}

Based on these results, considering the energy matrix and utilization of the coffee silverskin with residual oil, it was verified a potential of application in biotransformation reactions of crude oils with favorable physicochemical properties for the application, with the conversion of food by-products into value-added products.

\section{REFERENCES}

${ }^{1}$ NZEKOUE FK, ANGELONI S, NAVARINI L, ANGELONI C, FRESCHI M, HRELIA S, ET AL. Coffee silverskin extracts: Quantification of 30 bioactive compounds by a new HPLC-MS/MS method and evaluation of their antioxidant and antibacterial activities. Food Research International, v.133, p. 109128, 2020.

2 IRIONDO-DEHOND A, HERRERA T, CASTILLO MD. Health Benefits of Silverskin. Food Wastes By-products, v. 32, p. 353-71, 2020.

${ }^{3}$ BILBAO MDDC, EZEQUIEL MEI, BENAVENT MA, CALLEJA MH, MORAL MP DEL, ARTIZ MU. Application of products of coffee silverskin antiaging cosmetics and functional food. WO 2013/004873, v. 12, p. 67-73, 2013.

${ }^{4}$ SATO ST, MORIKAWA SH. Silver skin-containing paper and method for producing 
the same. US $7927460 \mathrm{B2}, 2011$.

${ }^{5}$ NARITA Y, INOUYE K. Review on utilization and composition of coffee silverskin. Food Research International, v. 61, p. 16-22, 2014.

${ }^{6}$ AOAC. Official Methods of Analysis. Assoc Off Agric Chem 1990;1.

${ }^{7}$ COMMISSION REGULATION (EEC). Official Journal of the European Communities. Off J Eur Communities, p. 2568, 1991.

${ }^{8}$ CARVALHO NB, BARBOSA JMP, OLIVEIRA MVS, FRICKS AT, LIMA ÁS, SOARES MF. Biochemical properties of Bacillus sp. ITP-001 lipase immobilized with a sol gel process. Quimica Nova, v. 36, p. 52-8, 2013.

9 SOARES CMF, SANTOS OA DOS, CASTRO HF DE, MORAES FF DE, ZANIN GM. Studies on Immobilized Lipase in Hydrophobic Sol-Gel. Applied biochemistry and biotechnology, v. 113, p. 307-19, 2004.

10 COSTA ASG, ALVES RC, VINHA AF, BARREIRA SVP, NUNES MA, CUNHA LM, ET AL. Optimization of antioxidants extraction from coffee silverskin , a roasting byproduct, having in view a sustainable process. Industrial Crops and Products, v. 53, p. 350-359, 2014.

11 TOSCHI TG, CARDENIA V, BONAGA G, MANDRIOLI M, RODRIGUEZ-ESTRADA MT. Coffee Silverskin : Characterization, Possible Uses, and Safety Aspects. Journal of Agricultural and Food Chemistry, v. 62, p. 10836-10844, 2014.

12 EFTHYMIOPOULOS I, HELLIER P, LADOMMATOS N, KAY A, MILLS-LAMPTEY B. Effect of Solvent Extraction Parameters on the Recovery of Oil From Spent Coffee Grounds for Biofuel Production. Waste and Biomass Valorization, v. 10, p. 253-64, 2019.

${ }^{13}$ AL-HAMAMRE Z, FOERSTER S, HARTMANN F, KRÖGER M, KALTSCHMITT M. Oil extracted from spent coffee grounds as a renewable source for fatty acid methyl ester manufacturing. Fuel, v. 96, p. 70-76, 2012.

14 HAILE M. Integrated volarization of spent coffee grounds to biofuels. Biofuel Research Journal, v. 2, p. 65-79, 2014.

15 SONNTAG NOV. New developments in the fatty acid industry. Journal of the American Oil Chemists' Society, v. 56, p. 861-864, 1979.

$16 \mathrm{GOH}$ BHH, ONG HC, CHONG CT, CHEN W-H, LEONG KY, TAN SX, ET AL. Ultrasonic assisted oil extraction and biodiesel synthesis of Spent Coffee Ground. Fuel, v. 261, p. 116-121, 2020.

17 KAPOOR M, GUPTA MN. Lipase promiscuity and its biochemical applications. Process Biochemistry, v. 47, p. 555-569, 2012.

18 MOTA DA, RAJAN D, HEINZL GC, OSÓRIO N, GOMINHO J, KRAUSE LC, ET AL. Production of low-calorie structured lipids from spent coffee grounds or olive pomace crude oils catalyzed by immobilized lipase in magnetic nanoparticles. Bioresource Technology, v. 307, p. 123-129, 2020. 